\title{
BENTUK DAN MAKNA UNGKAPAN FATIS \\ DALAM BAHASA DAYAK NGAJU
}

\author{
(Form and Meaning of Pathics in Dayak Ngaju Language)
}

\author{
Muston N.M. Sitohang \\ Balai Bahasa Provinsi Kalimantan Tengah \\ Jalan Tingang Km. 3,5, Palangka Raya, Kalimantan Tengah 73112 \\ Pos-el: sitohangmuston76@gmail.com
}

(Naskah Diterima 22 September 2021—Direvisi 13 Oktober 2021—Disetujui 15 Oktober 2021)

\begin{abstract}
This article discussed forms and meanings of phatic in the Ngaju Dayak language. The data was obtained by recording technique. The findings of this study indicated that in the Ngaju Dayak language of Central Kalimantan, phatic expressions are delivered verbally. In general, phatic expressions in the Ngaju Dayak are in particles and words. Based on interviews with natives, there are several phatic expressions in the Ngaju Dayak. Some of the phatices found were in the form of particles bah, beh, bei, boh, ceh, ces, cih, cuh, duh, has, hey, hi and ih. Fatices in the form of words are akayah (-lah), and akuy. The phatic meaning of the particle is to show (1) sense of wonder, (2) annoyance, (3) amazement, (4) anger, (5) disappointment, (6) disgust, (7) condescension, (8) welcome, (9) affirmation, and (10) rebuke. While the meaning of phatic in the form of words are to express (1) pain, (2) awe, (3) joy, and (4) affirmation. The research also showed that some phatics in the Ngaju Dayak language are in positive communication, some of them actually have the meaning of demeaning, rebuking, and feeling angry.
\end{abstract}

Keywords: Ngaju Dayak, particle, phatic, word

\begin{abstract}
Abstrak
Artikel ini membahas bentuk dan makna fatis dalam bahasa Dayak Ngaju. Data diperoleh dengan teknik rekam catat dan selanjutnya dideskripsikan bentuk dan maknanya. Temuan penelitian ini menunjukkan ungkapan fatis disampaikan secara verbal oleh penutur bahasa Dayak Ngaju Kalimantan Tengah. Pada umumnya ungkapan fatis dalam bahasa Dayak Ngaju berupa partikel dan kata. Berdasarkan wawancara dengan penutur, terdapat beberapa ungkapan fatis dalam bahasa Dayak Ngaju. Beberapa fatis yang ditemukan berbentuk partikel, yaitu bah, beh, bei, boh, ceh, ces, cih, cuh, duh, has, hei, hi, dan ih. Berbentuk kata, yaitu akayah (-lah) dan akui. Makna fatis berupa partikel menunjukkan (1) rasa heran, (2) rasa jengkel, (3) rasa takjub, (4) rasa geram, (5) rasa kecewa, (6) rasa jijik, (7) merendahkan, (8) mempersilakan, (9) penegasan, dan (10) hardikan. Fatis berupa kata mengungkapkan (1) rasa sakit, (2) rasa kagum, (3) rasa gembira, dan (4) penegasan. Penelitian ini juga menunjukkan bahwa beberapa fatis dalam bahasa Dayak Ngaju digunakan tidak untuk membangun komunikasi yang positif, beberapa fatis tersebut justru mempunyai makna merendahkan, hardikan, dan rasa geram.
\end{abstract}

Kata kunci: Dayak Ngaju, fatis, kata, partikel 


\section{PENDAHULUAN}

Manusia selalu berinteraksi dengan menggunakan bahasa dalam kehidupan bermasyarakat. Bahasa sebagai alat komunikasi dimanfaatkan dalam berbagai hal, seperti komunikasi sosial, budaya, dan keagamaan. Bahasa dapat digunakan untuk menyampaikan pikiran, gagasan, atau perasaan. Bahasa juga memiliki pengaruh luar biasa yang menjadi salah satu pembeda manusia dengan makhluk hidup lainnya. Keraf mengemukakan empat fungsi bahasa, yaitu (1) sebagai alat untuk menyatakan ekspresi diri, (2) alat komunikasi, (3) alat mengadakan integrasi dan adaptasi sosial, dan (4) alat untuk mengadakan kontrol sosial (Keraf, 2004).

Komunikasi yang baik tentu saja menggunakan ragam bahasa yang sesuai dengan situasi dan kondisi tuturan dan peruntukannya. Jika melibatkan penutur yang beragam, tentu saja diperlukan bahasa yang dapat dimengerti dan dapat dituturkan oleh semua orang. Namun, jika digunakan oleh kelompok penutur dari suku bangsa tertentu, bahasa yang digunakan adalah bahasa suku itu sendiri. Sejalan dengan pernyataan di atas, Leibniz (dalam Sukri, 2008) mengatakan bahwa bahasa adalah cermin terbaik pikiran manusia (language is the best mirror of human thought).

Ujaran-ujaran yang menunjukkan kedekatan hubungan antarpenutur tersebut kadang-kadang muncul secara spontan sehingga membuat jalannya percakapan lebih komunikatif. Kekomunikatifan tersebut ditandai dengan munculnya kata-kata tertentu yang sepintas tidak memiliki makna, tetapi mampu membuka percakapan, mempertegas, atau memperhalus tuturan atau ungkapan.

Salah satu fungsi bahasa adalah fungsi fatis. Ungkapan atau ujaran yang bersifat fatis tidak berisi hal-hal yang menyangkut informasi atau ide-ide yang ingin disampaikan oleh penutur, tetapi bertujuan untuk mendekatkan atau mengeratkan hubungan antara penutur dan mitra tutur.

Menurut Kridalaksana, kategori fatis adalah kategori yang bertugas memulai, mempertahankan, atau mengukuhkan komunikasi antara pembicara dan kawan bicara (Kridalaksana, 2008). Sebagian besar kategori fatis merupakan ciri lisan. Kelas kata itu biasanya terdapat dalam konteks dialog atau wawancara bersambutan. Sebagian besar kategori fatis merupakan ciri ragam lisan nonstandar yang banyak mengandung unsur-unsur daerah atau dialek. Pada umumnya bentuk fatis terdapat di awal, tengah, dan akhir kalimat. Kridalaksana juga membagi kategori fatis menjadi tiga bentuk, yaitu partikel fatis, kata fatis, dan frasa fatis.

Tidak jauh berbeda dari bahasa Indonesia, ungkapan-ungkapan fatis pada bahasa daerah muncul dalam berbagai bentuk. Hal yang perlu diperhatikan adalah bentuk-bentuk fatis dalam bahasa daerah tersebut tidaklah sama walaupun tujuannya sama, yaitu menunjukkan keakraban.

Beberapa penelitian yang terkait dengan bentuk dan ungkapan fatis dalam bahasa daerah telah dilakukan oleh beberapa peneliti. Salah satunya dilakukan Thaufik, dkk. Ia meneliti bentuk fatis dalam bahasa Melayu dialek Kuok di daerah Kuok, Kabupaten Kampar, Riau (Thaufik et al., 2015). Mereka menyimpulkan bentuk-bentuk fatis yang muncul dalam bahasa Melayu dialek Kuok berupa kata, frasa, dan gabungan.

Penelitian lain terkait fatis dilakukan Pala. Ia meneliti bentuk fatis dalam bahasa Bugis Soppeng (Pala, 2015). Dalam bahasa Bugis Soppeng 
bentuk fatis terdiri atas bentuk kata, frasa, dan kalimat.

Penulis melihat situasi kebahasaan di Kalimantan Tengah, terutama yang terkait dengan fatis, belum pernah diangkat. Pada artikel ini penulis berasumsi bahwa penggunaan fatis dalam bahasa Dayak Ngaju memiliki beberapa perbedaan dengan fatis dalam bahasa Indonesia atau bahasa daerah lain. Berdasarkan pengamatan penulis, dalam bahasa Dayak Ngaju beberapa kata atau frasa fatis digunakan bukan dalam situasi yang positif, namun kadang-kadang dalam situasi negatif, seperti perkelahian, cacian, atau melecehkan lawan bicara. Hal itu bertentangan dengan Malinowski yang mengatakan bahwa ungkapan fatis merupakan tipe tuturan yang digunakan untuk menciptakan ikatan sosial yang harmonis dengan semata-mata bertukar kata-kata (dalam Waridin, 2008).

Fatis secara etimologi berasal dari bahasa Yunani phatos, bentuk verba dari phatai 'berbicara' (Yusra, 2012). Menurut Kridalaksana, kategori fatis adalah kategori yang bertugas untuk memulai, mempertahankan, atau mengukuhkan komunikasi antara pembicara dan kawan bicara (Kridalaksana, 2008). Kelas kata itu biasanya terdapat dalam konteks dialog wawancara bersambutan, yaitu kalimat yang diucapkan oleh pembicara dan kawan bicara. Sebagian besar kategori fatis merupakan ciri ragam lisan.

Ragam lisan tersebut pada umumnya merupakan ragam nonstandar sehingga kebanyakan kategori fatis terdapat dalam kalimat-kalimat nonstandar yang banyak mengandung unsur-unsur daerah atau dialek regional. Bentuk fatis dapat mucul di awal, tengah, atau akhir kalimat. Contoh bentuk fatis dalam bahasa Indonesia di antaranya kok, deh, dan selamat.

Menurut Kridalaksana, kategori fatis dalam bahasa Indonesia memiliki tiga bentuk, yaitu partikel fatis, seperti $a h$, deh, dong, ding, kan, kek, kok, lah, lho, nah, pun, sih, toh, dan yah. Selain partikel, kategori fatis juga memiliki bentuk berupa kata fatis, seperti ayo, selamat, dan ya. Bentuk yang terakhir adalah frasa, seperti selamat malam, selamat datang, asalamualaikum, waalaikum salam, terima kasih, dan insyaallah.

Kridalaksana juga mengatakan bahwa tiap bentuk kategori fatis dalam bahasa Indonesia memiliki distribusi yang berbeda. Ada yang terdapat di awal kalimat, seperti nah dalam "nah, ini yang lebih bagus" dan terima kasih dalam "terima kasih, Pak". Ada pula yang terdapat di tengah kalimat, seperti kek dalam "mau marah kek, terserah", lah dalam "bawalah bukunya", dan toh dalam "biarin aja, toh dia yang punya". Ada juga yang terdapat di akhir kalimat, seperti sih dalam "bener juga, sih" atau di awal dan akhir kalimat, seperti selamat dalam "selamat, ya", dan yah dalam "jangan pulang dulu, yah".

Kategori fatis dalam bahasa Indonesia memiliki fungsi yang berbeda, yaitu (1) ah menekankan rasa penolakan atau tak acuh, (2) ayo menekankan ajakan, (3) deh untuk menekankan dengan membujuk, persetujuan, sekadar penekanan, (4) dong untuk menghaluskan perintah dan menekankan kesalahan kawan bicara, (5) ding untuk menekankan pengakuan kesalahan pembicara, (6) halo digunakan untuk memulai dan mengukuhkan pembicaraan di telepon dan menyalami kawan bicara yang dianggap akrab, (7) kan yang jika terletak di akhir atau awal kalimat merupakan kependekan dari kata bukan atau bukankah dan berfungsi menekankan pembuktian; jika terletak di tengah kalimat, kan bersifat menekankan pembuktian atau bantahan, (8) kek mempunyai fungsi menekankan pemerincian, perintah, dan menggantikan 
kata saja, (9) kok menekankan alasan, pengingkaran, dan kadang-kadang berfungsi sebagai pengganti kata tanya mengapa, (10) lah menekankan kalimat imperatif dan penguat sebutan dalam kalimat, (11) lho berfungsi seperti interjeksi yang menyatakan kekagetan atau menekankan kepastian, (12) nah untuk meminta supaya kawan bicara mengalihkan perhatian kepada hal lain, (13) pun bertugas menonjolkan bagian tersebut, (14) selamat diucapkan kepada kawan bicara yang mendapatkan atau mengalami sesuatu, (15) sih memiliki tugas menggantikan tugas tah dan kah, bermakna memang atau sebenarnya dan menekankan alasan, (16) toh bertugas menguatkan maksud atau kadang-kadang memiliki arti yang sama dengan tetapi, (17) ya bertugas mengukuhkan atau membenarkan apa yang ditanyakan kawan bicara, minta persetujuan atau pendapat kawan bicara, (18) yah berfungsi untuk mengungkapkan keraguan atau ketidakpastian terhadap apa yang diungkapkan oleh kawan bicara atau yang tersebut dalam kalimat sebelumnya, (19) terima kasih digunakan setelah pembicara merasa mendapatkan sesuatu dari kawan bicara, (20) asalamualaikum berfungsi memulai interaksi, (21) waalaikumsalam digunakan untuk membalas salam kawan bicara, dan (22) insyaallah diucapkan oleh pembicara ketika menerima tawaran mengenai sesuatu dari kawan bicara.

Dengan demikian, pengertian partikel fatis dalam tulisan ini adalah kata atau partikel yang mempunyai ciri-ciri (1) memiliki bentuk khusus, yaitu sangat ringkas atau kecil, (2) mempunyai tujuan untuk menghidupkan percakapan dan suasana, (3) umumnya hadir dalam ragam lisan (percakapan) dan dalam ragam tulis yang bersifat tidak resmi, dan (4) umumnya mempunyai fungsi menegaskan kata atau kalimat.

\section{METODE PENELITIAN}

Penelitian ini termasuk jenis penelitian deskriptif kualitatif. Menurut Fraenkel dan Wallen, penelitian deskriptif kualitatif adalah studi yang penekanannya berhubungan dengan aktivitas-aktivitas, situasi-situasi, atau bahan-bahan yang memerlukan deskripsi yang utuh tentang sesuatu (Fraenkel, J.R. et al, 2007).

Data penelitian ini adalah kata-kata fatis dalam bahasa Dayak Ngaju. Data diperoleh dengan teknik wawancara, catat, dan rekam. Informan penelitian adalah dua orang penutur jati bahasa Dayak Ngaju yang masing-masing berusia 38 dan 45 tahun dan berdomisili di Kota Palangka Raya.

Data diklasifikasi, selanjutnya dijelaskan makna dan bentuknya berdasarkan teori yang ada. Penelitian ini berfokus kepada penggunaan fatis yang muncul pada percakapan sehari-hari masyarakat penutur bahasa Dayak Ngaju dalam berbagai situasi, baik formal maupun nonformal.

\section{PEMBAHASAN}

Bentuk fatis dalam bahasa Dayak Ngaju dipergunakan masyarakat di wilayah Kalimantan Tengah dalam suasana nonformal. Setelah melakukan wawancara dengan penutur diketahui bahwa dalam bahasa Dayak Ngaju fatis berbentuk partikel dan sebagian dalam bentuk kelompok kata. Fatis dalam kelompok partikel terdiri atas bah, beh, bei, boh, cah, ceh, ces, cih, cuh, duh, has, $h e i$, hi, dan $i h$, sedangkan yang berupa kata ialah akay dan akui.

\section{Partikel}

Bah

Partikel bah dalam bahasa Dayak Ngaju umumnya diletakkan di awal dan tengah 
kalimat. Partikel bah mempunyai dua makna, yaitu mengungkapkan dan menegaskan kejengkelan. Berikut beberapa contoh penggunaan bah dalam kalimat.

(1) Bah, narai mawi uluh jete dari-dari bentuk andau. 'Apa yang membuat orang itu lari di siang hari'.

(2) Ela gulei ramu tuh! Bah, hiningmauhku! Jangan pegang benda ini, kau dengar kataku!'

Pada contoh (1) partikel bah terletak di awal dan pada contoh (2) terletak di tengah kalimat. Partikel bah pada kedua contoh tersebut berfungsi sebagai penegas konteks kalimat. Fatis bah memiliki kesamaan makna dengan fatis kah dan lah dalam bahasa Melayu Riau dialek Kuok yang menyatakan penegas kejengkelan atau kekesalan (Faizah, 2012).

\section{Beh}

Partikel beh umumnya diletakkan di awal kalimat, tidak ditemuan di tengah atau akhir kalimat. Partikel beh bermakna penegasan/pembenaran atas pernyataan sebelumnya. Berikut contoh penggunaan beh dalam kalimat.

(3) Beh, dia sala kuangku endau, puna uluh te je manduae. '(Nah) tidak salah kataku tadi, memang orang itu yang mengambilnya'.

Pada contoh (3) di atas, partikel beh terletak di depan kalimat dan bermakna penegasan atau pembenaran atas pernyataan sebelumnya. Partikel beh pada contoh tersebut memiliki kesetaraan makna dengan nah dalam bahasa Indonesia. Fatis beh memiliki kesamaan makna dengan fatis kan dalam bahasa Melayu Riau dialek Kuok yang menyatakan penegas kejengkelan atau kekesalan (Faizah, 2012).
$\mathrm{Bei}$

Partikel bei dalam bahasa Dayak Ngaju umumnya diletakkan di tengah dan akhir kalimat. Partikel bei mempunyai makna mempersilakan atau permintaan. Berikut beberapa contoh penggunaan bei dalam kalimat.

(4) Duan bei bua je manjatu te. 'Ambil (lah) buah yang jatuh itu'.

(5) Palepah bei. 'Habiskan (saja)'.

Pada contoh (4) dan (5) di atas partikel bei bermakna permintaan atau mempersilakan. Partikel bei pada kalimat contoh tersebut memiliki kesetaraan makna dengan lah dan saja. Jenis fatis itu mempunyai kesamaan makna dengan ciek dalam bahasa Melayu Kampar Kiri yang bermakna permintaan (Thaufik et al., 2015).

\section{Boh}

Partikel boh dalam bahasa Dayak Ngaju umumnya diletakkan di awal dan tidak ditemukan di tengah atau akhir kalimat. Partikel boh mempunyai makna keheranan. Berikut beberapa contoh penggunaan boh dalam kalimat.

(6) Boh, kilen ampie tau paim bahimang? 'Bagaimana bisa kakimu terluka?'

(7) Boh, manarewen aku salentup ban te. 'Mengejutkanku letusan ban itu'.

Pada contoh (6) dan (7) itu partikel boh bermakna keheranan dan rasa kaget atau heran. Jenis fatis ini memiliki kesamaan arti dengan ha dan gai dalam bahasa Melayu Riau dialek Kiri (Thaufik et al., 2015).

Cah

Partikel cah dalam bahasa Dayak Ngaju umumnya diletakkan di awal kalimat, tidak ditemukan di tengah atau akhir kalimat. Partikel cah mempunyai makna 
penegasan dan penolakan. Berikut beberapa contoh penggunaan $c a h$.

(8) Cah, bara huran palus tuh bagare buring pasti babilem. '(Sudah) sejak dulu hingga kini yang namanya arang pasti berwarna hitam'.

(9) Cah, aku dia maku manduan panengam. '(Sudahlah) aku tidak mau mengambil pemberianmu'.

Pada contoh (8) dan (9) partikel cah bermakna penegasan dan penolakan. Partikel ceh pada kedua kalimat contoh tersebut sejajar dengan kata sudah atau sudahlah dalam bahasa Indonesia. Jenis fatis ini memiliki kesamaan arti dengan fatis $b a$ dalam bahasa Bugis Soppeng (Pala, 2015).

\section{Ceh}

Partikel ceh umumnya diletakkan di awal kalimat, tidak ditemukan di tengah atau akhir kalimat. Partikel ceh mempunyai makna menekankan pembuktian. Berikut beberapa contoh penggunaan $c e h$.

(10) Ceh, puna dia ikei manenga akae. '(Yah) memang kami tidak memberi untuknya'.

(11) Ceh, jatun karewangmu manggawi te. '(Yah) tidak ada kemampuanmu mengerjakannya'.

Pada contoh (10) dan (11) partikel ceh bermakna penegasan dan pembuktian atas ketidakmampuan. Fatis ceh pada kedua kalimat contoh tersebut sejajar dengan yah dalam bahasa Indonesia. Jenis fatis ini memiliki kesamaan arti dengan fatis kan dalam bahasa Melayu Riau dialek Kiri (Thaufik et al., 2015).

Ces

Partikel ces umumnya diletakkan di awal kalimat, tidak ditemukan di tengah dan akhir kalimat. Partikel ces mempunyai makna geregetan. Berikut beberapa contoh penggunaan ces dalam kalimat.

(12) Ces, handak angatku mamedak asu te. 'Ingin rasaku melempar anjing itu'.

Pada contoh (12) partikel ces bermakna geregetan dan hanya merupakan penegas konteks. Jenis fatis ini mempunyai kesamaan makna dengan fatis $k a$ dalam bahasa Melayu Kampar Kuok yang bermakna rasa geram (Faizah, 2012).

Cuh

Partikel cuh umumnya diletakkan di awal kalimat, tidak ditemukan di tengah atau akhir kalimat. Partikel cuh mempunyai makna kemarahan atau kegeraman, seperti seolah-olah meludah. Berikut contoh penggunaan $c u h$ dalam kalimat.

(13) Cuh, ela jujuan mamaksa uluh amun dia handak pehe. 'Jangan ngotot memaksa orang jika tidak ingin sakit'.

Pada contoh (13) bermakna rasa marah atau geram. Partikel cuh pada kalimat contoh tersebut berfungsi sebagai penegas konteks kalimat. Jenis fatis ini memiliki kesamaan arti dengan fatis $k o$ dalam bahasa Melayu Riau dialek Kiri (Thaufik et al., 2015).

\section{Duh}

Partikel duh umumnya diletakkan di awal kalimat, tidak ditemukan di tengah atau akhir kalimat. Partikel duh mempunyai makna penyesalan. Berikut beberapa contoh penggunaan $d u h$ dalam kalimat.

(14) Duh, jaka tawangku kahem, dia umba tulak aku. '(Aduh) andai aku tahu karam, aku tidak ikut pergi'.

Pada contoh (14) partikel duh bermakna penyesalan. Partikel duh pada contoh 
tersebut setara dengan aduh dalam bahasa Indonesia. Fatis duh dalam bahasa Indonesia mewakili kata maaf yang berarti mengungkapkan penyesalan (Rimawati, 2017).

Has

Partikel has umumnya diletakkan di awal kalimat dan tidak ditemukan di tengah atau akhir kalimat. Partikel has mempunyai makna ajakan untuk bergegas. Berikut contoh penggunaan has dalam kalimat.

(15) Has, jeleng itah tulak, kareh liwat. '(Ayo) lekas kita pergi, nanti terlambat'.

Pada contoh (15) partikel bermakna ajakan dan sejajar dengan ayo dalam bahasa Indonesia. Jenis fatis ini memiliki kesamaan arti dengan fatis nye dalam bahasa Melayu Riau dialek Kiri yang menekankan intensitas keadaan (Thaufik et al., 2015).

\section{$\mathrm{Hei}$}

Partikel hei umumnya diletakkan di awal kalimat dan tidak ditemukan di tengah atau akhir kalimat. Partikel hei mempunyai makna takjub, hardikan, teguran, dan kekecewaan. Berikut beberapa contoh penggunaan hei dalam kalimat.

(16) Hei, mias kagantung kayu hai tuh. '(Wah) luar biasa tingginya pohon ini'.

(17) Hei, buhau bara hete! 'Pergi dari situ!'

(18) Hei, paheka itah tulak bagawi, jatun pandinu. 'Membuat lelah kita saja, pergi bekerja tidak ada hasil'.

Pada contoh (16) partikel hei bermakna takjub dan sejajar dengan wah dalam bahasa Indonesia. Pada contoh (17) partikel hei bermakna hardikan, sedangkan pada contoh (18) bermakna kekecewaan. Partikel hei pada kedua contoh tersebut sejajar dengan aduh dalam bahasa Indonesia. Jenis fatis ini memiliki kesamaan arti dengan fatis jek dalam bahasa Bugis Soppeng (Pala, 2015).

Ih

Partikel ih umumnya diletakkan di awal dan kadang-kadang di tengah kalimat. Partikel ih mempunyai makna penegasan penolakan dan mempersilakan.Berikut beberapa contoh penggunaan ih dalam kalimat.

(19) Ih, aku dia maku. '(Tidak) aku tidak mau'.

Pada contoh (19) partikel ih bermakna penegasan penolakan. Jenis fatis ini memiliki kesamaan arti dengan fatis mbok dalam bahasa Bugis Soppeng (Pala, 2015).

$\mathrm{Hi}$

Partikel hi umumnya diletakkan di awal dan kadang-kadang di akhir kalimat. Partikel $h i$ mempunyai makna jijik dan menakut-nakuti seseorang. Berikut beberapa contoh penggunaan partikel $i h$.

(20) Hi, inganan kejau kanih metu je maram te! 'Dibuang jauh sana binatang yang busuk itu!'

(21) Hi, payah, metu narai tuh je melai lengengku tuh? 'Lihat! Binatang apa di tanganku ini?'

Pada contoh (20) partikel hi bermakna jijik, sedangkan pada contoh (21) bermakna menakut-nakuti. Jenis fatis ini mempunyai kesamaan makna dengan fatis liok dalam bahasa Melayu Kampar Kuok yang bermakna menekankan suatu hal (Faizah, 2012). 


\section{Kata}

Akay

Kata akay dalam bahasa Dayak Ngaju umumnya diletakkan di awal kalimat. Partikel akay mempunyai beberapa makna, yaitu mengungkapkan rasa sakit, kekaguman, kegembiraan, dan ungkapan untuk merasakan hal yang sama. Kata akay juga kadang-kadang diakhiri dengan partikel lah. Berikut beberapa contoh penggunaan akay dalam kalimat.

(22) Akay! Salenga pehe kuluk ututku. 'Aduh! Mendadak sakit lututku'.

(23) Akay kahalap bajum. 'Aduh bagusnya bajumu'.

(24) Akay! Kasabaingku dinun lauk hai. '(Aduh) keberuntunganku mendapat ikan besar'.

(25) Akaylah, pasi aku payah uluh te. 'Iba aku melihat orang itu'.

Kata akay pada contoh (22) bermakna ungkapan rasa sakit, sedangkan akay memiliki makna kekaguman pada contoh (23). Pada contoh (24), akay bermakna ungkapan kegembiraan. Pada contoh (25) akay bermakna menunjukkan rasa turut merasakan hal yang sama.

\section{Akui}

Kata akui umumnya diletakkan di awal kalimat. Kata akui mempunyai beberapa makna, yaitu mengungkapkan kekaguman dan penyesalan. Biasanya kata akui dapat diakhiri dengan partikel lah. Berikut beberapa contohnya.

(26) Akui, kahain human ketun. 'Akui, besarnya rumah kalian'.

(27) Akuilah, jaka tau imbalang aku mahatangan ie awi duitku innempute. 'Aduhlah, andai bisa kubatalkan memberi pinjaman padanya karena uangku dibawanya kabur'.
Pada contoh (26) kata akui bermakna menunjukkan kekaguman, sedangkan pada (27) mengungkapkan penyesalan.

Fatis yang ditemukan pada penelitian ini jika mengacu kepada beberapa penelitian fatis dalam bahasa daerah lain memiliki kesamaan bentuk, yaitu partikel dan kata. Jika dilihat dari makna, kata fatis dalam bahasa daerah lain cenderung memiliki satu makna. Namun, dalam bahasa Dayak Ngaju ada beberapa kata fatis yang bermakna lebih dari satu.

Partikel hei memiliki makna rasa kagum, rasa marah, dan rasa kecewa. Kata fatis akay memiliki makna rasa sakit, rasa kagum, dan rasa gembira. Uniknya, makna kata fatis akay saling bertolak belakang sehingga perlu kecermatan dalam membangun konteks kalimatnya.

\section{PENUTUP}

Berdasarkan hasil kajian dan pembahasan dapat disimpulkan bahwa bentuk fatis dalam bahasa Dayak Ngaju berupa partikel terdiri atas bah, beh, bei, boh, ceh, ces, cih, cuh, duh, has, hei, hi, dan ih. Makna fatis-fatis tersebut adalah menunjukkan rasa heran, jengkel, takjub, kecewa, jijik, geram, penegasan, mempersilakan, merendahkan lawan bicara, dan hardikan. Makna fatis berupa kata yang ditemukan adalah akayah dan akui. akayah dan akui digunakan untukmengungkapkan rasa sakit, kekaguman, kegembiraan, dan penegasan.

Hasil analisis juga menunjukkan bahwa terdapat beberapa fatis yang tidak membangun komunikasi yang positif antarpenutur, seperti partikel cah dan $h i$, yang bermakna penolakan dan penekanan rasa jijik.

Penelitian terkait dengan fatis memungkinkan untuk dikembangkan karena sumber data penelitian ini hanya 
diperoleh dari satu wilayah penutur, sedangkan bahasa Dayak Ngaju di Kalimantan Tengah tersebar di enam kabupaten dan kota.

\section{DAFTAR PUSTAKA}

Faizah, H. (2012). Kategori Fatis dalam Bahasa Melayu Riau Dialek Kuok. Litera, 11(1), 60-70. https://doi.org/10.21831/ltr.v11i1.1 147

Fraenkel, J.R., Norman, E. W. (2007). How to Design and Evaluate Research and Education. New York: McGraw-Hill.

Keraf, G. (2004). Komposisi: Sebuah Pengantar Kemahiran Bahasa. Ende: Nusa Indah.

Kridalaksana, H. (2008). Kelas Kata dalam Bahasa Indonesia. Jakarta: Gramedia.

Pala, R. (2015). Bentuk Komunikasi Fatis dalam Bahasa Bugis Soppeng. Sawerigading, 21(3).

Rimawati, A. W. (2017). Komunikasi Fatis dalam Wacana Konsultatif. Skripsi. Universitas Sanata Dharma.

Sukri, M. R. (2008). Bahasa dalam Realitas Sosial. Mataram: Lembaga Cerdas Press.

Thaufik, G., Fauziah, H., \& Ermanto. (2015). Kategori Fatis dalam Bahasa Melayu Kampar Kiri Kabupaten Kampar. Bahasa, Sastra, dan Pembelajaran, 3(1), 46-70.

Waridin. (2008). Ungkapan Fatis dalam Acara Temu Wicara Televisi. Disertasi. Universitas Indonesia.

Yusra, H. (2012). Kategori Fatis Bahasa Minangkabau dalam Kaba Racak di Labuah. Skripsi. Universitas Negeri Padang. 